RESEARCH PAPER

\title{
Analysis of the contributions and proposals for improvement of a municipal higher education institution under the prism of different stakeholders
}

\author{
Ridley Gomes Franzoso, Fernando Oliveira de Araujo², Chrystyane Gerth Silveira Abreu³ \\ ${ }^{1}$ Fluminense Federal University, Niterói, RJ, Brazil. \\ ${ }^{2}$ Department of Production Engineering, Fluminense Federal University, Niterói, Brazil. \\ ${ }^{3}$ Federal Center for Technological Education Celso Suckow da Fonseca - CEFET, Postgraduate Program in Productive Systems \\ and Regional Development, Rio de Janeiro, RJ, Brazil.
}

How to cite: Franzoso, R.G., Araujo, F.O. and Abreu, C.G.S. (2020), "Analysis of the contributions and proposals for improvement of a municipal higher education institution under the prism of different stakeholders", Brazilian Journal of Operations \& Production Management, Vol. 17, No. 03, e2020988.

https://doi.org/10.14488/BJOPM.2020.037

\begin{abstract}
Goals: The research aimed to identify the main benefits of a municipal institution of higher education (HEI) from the point of view of the most distinct groups of interest, such as city hall, companies, teachers, students and those responsible., characterizing the main key actors/ interlocutors and analyzing their perceptions regarding the role of this $\mathrm{HEI}$ in the development of the Region. Considering this relevant input, the study systematizes a set of actions capable of improving the various socioeconomic benefits of the institution.

Design / Methodology / Approach: Interviews were conducted with City representatives, teachers, students, community members, and local companies, in order to verify their comments and views in relation to the IES studied.

Results: The results of the investigation and surveys were supporting in a large extent the opinion of the stakeholders participating in this studied, which recognized the relevance of the Municipal IES for this region.

Limitations of the investigation: The study is limited to a single Higher education Institution located on the northern coast of the State of Rio de Janeiro, Brazil. Having not been done comparisons with other similar entities.

Practical implications: Presents a special contribution of this Institution to the feasibility and democratization of access to public, free, high quality education at night hours.

Originality / Value: This is a peculiar case, since this IES is budgeted by the Municipality, being after regular working hours (at night), and offered free of charge.
\end{abstract}

Keywords: Municipal Educational Institution Superior; Public Education; Access to Education; Analysis Multi-Stakeholder.

\section{INTRODUCTION}

Higher education is an important tool for promoting development. At Brazilian level, since 2003, under the Presidency of Luiz Inácio Lula da Silva, actions were taken to expand and internalize Higher education, particularly among them, a relevant public policy is the REUNI Program to Support Plans for Restructuring and Expansion of Federal Universities, which has as main objective to expand access and stay of Higher education, established by Decree

Financiamento: None

Conflict of interest: None.

Corresponding author: ridley137@outlook.com

Received: 31 May 2020

Accepted: 26 July 2020

Editor: Fernando Oliveira de Araujo and Chrystyane Abreu 
No. 6,096/2007. This is one of the actions that integrate the Education Development Plan (PDE).

A country of continental dimensions, Brazil has as one of its important challenges, to develop its territory homogeneously avoiding large concentrations as occurs today in large capitals.

In this regard, one of the aspects that stimulated this concentration, in addition to economic reasons, was the offer of Higher education courses almost exclusively in the capitals, which caused students from the interior to live four to five years in the capital and in many cases settled in these regions to pursue their professional career (Nascimento, 2013)

Been one of the primary responsibility of the Union to Higher education, as indicated by the Federal Constitution, which still assigns to the States as a priority elementary and high school (art. 211, § 3, of the C.F.) and to the Municipalities and Federal District, programs of early childhood education and high school, both in partnership to achieve a good performance. However, the possibility is open for the State or the Municipality to act in other spheres of education and education once each of them is fulfilling its priorities (art. 211, § 2, C.F.).

The Basic Guidelines Of National Education (LDB) Laws of 1968 and 1996 worked notably to establish a unique organizational model for public and private universities, as well as the beginning of the process of restructuring Higher education in Brazil, in addition to including guidelines for the expansion and internalization of Higher education, including the mandatory offer of night courses in public Institutions, as per art. 47 from Capt. IV. (Brasil, Ministério da Educação, 2011).

It is important to clarify that even the LDB updated in June 2018, nothing more mentions of novelty about Higher education (Brasil, 2018) and did not specify about a process of internalization of Higher Education Institutions (HEls). However, there was an increase in the number of HEls from 1996 to 2001 of $51 \%$, but for the interior of the States, the north and northeast achieved almost half of the growth (Tavares, 2013). Thus, in many Brazilian states there was a lack of HEls outside the capitals, as in the case of Rio de Janeiro.

It is in the PNE 2014 - 2024 (Law n. 130005/2014) that best determines guidelines, goals and strategies for educational policy in the period 2014 to 2024 (Souza, 2014; Melo and Moura, 2017). The excerpt from Goal 12 of the PNE deals with Higher education. In particular, three strategies, such as the most relevant ones, in relation to the expansion and internalization of HEls, are brought to the discussion:

- Optimize the installed capacity of the physical structure and human resources of public Institutions of Higher education, through planned and coordinated actions, in order to expand and internalize access to graduation;

- Expand the offering, through the expansion and internalization of the federal network of Higher education, the Federal Network of Professional, Scientific and Technological Education and the Open University of Brazil system [...].

- Gradually raising the average completion rate of in-person undergraduate courses in public universities to $90 \%$ (ninety percent), offering at least one third of the vacancies in night courses [...].

Although public policy, in its formulation, proves to be comprehensive and inclusive, in a relevant region of the State of Rio de Janeiro, on the north coast of Rio de Janeiro - a region of the prosperous oil industry until the year 2000 , there was no action of the federal government in the sense of offering free and night-time Higher education.

On the other hand, in order to overcome the enormous demands of the region, one of the Municipalities in the region, despite its constitutional responsibility, called for itself the responsibility of offering Higher education courses in the technological area, founding a free and nocturnal HEI in 2000. This college has always had a great social relevance, due to the huge lack of Higher education in the Municipality, in whose closest public HEls is more than $100 \mathrm{~km}$ away. 


\section{Situation-Problem Description}

The role of Municipalities in Higher education is extremely punctual in Brazil, with only 2.6\% of the HEls existing in the country as shown in Figure 1. In particular, the State of Rio de Janeiro has only one, located on the north coast of Rio de Janeiro (Instituto Nacional de Estudos e Pesquisas Educacionais Anísio Teixeira, 2017).

\begin{tabular}{|c|c|c|c|c|c|c|c|c|c|}
\hline \multirow{2}{*}{ Year } & \multirow{2}{*}{ Total } & \multicolumn{2}{|c|}{ University } & \multicolumn{2}{|c|}{ University Center } & \multicolumn{2}{|c|}{ College } & \multicolumn{2}{|c|}{ IF and Cefet } \\
\hline & & Public & Private & Public & Private & Public & Private & Public & Private \\
\hline 2017 & 2,448 & 106 & 93 & 8 & 181 & 142 & 1,878 & 40 & n.a. \\
\hline
\end{tabular}

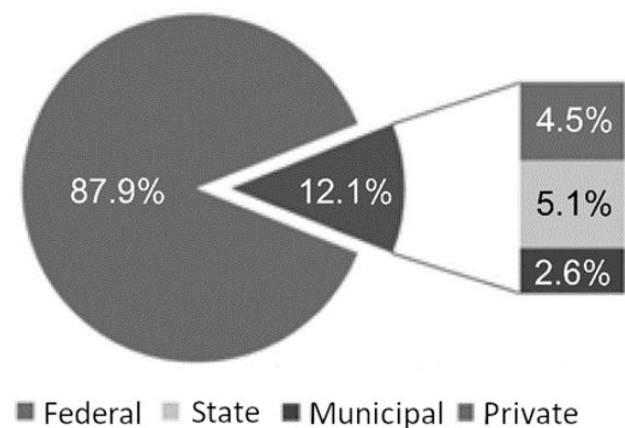

Figure 1. Higher Education Institutions, by Academic Organization and Administrative Category (2017) Source: Adapted from Instituto Nacional de Estudos e Pesquisas Educacionais Anísio Teixeira (2017)

This extremely prosperous city, with per capita income 3 times the national average (Instituto Brasileiro de Geografia e Estatistica, 2015), did not have a Federal presence in Higher education. The demand for skilled labor was high and the many companies in the region used to bring professionals trained from other Brazilian cities, while the Municipality had no way to develop its citizens.

Thus, at the initiative of the city, through an Education Foundation, a Municipal college was founded that has as its characteristic to be beyond everything inclusive, given the offer of Higher education courses in night time, which enables the participation of people who need to work, being also family risk.

For 7 years, this college was the only one to offer quality public Higher education. It turns out that in 2007, according to the model of internalization of the teaching of the federal network, two federal universities of RJ also placed educational centers at the city, although with daytime offer only.

Faced with a crisis in the oil industry from 2014 and consequently impacts on the collection of Municipalities in the region of the north coast of Rio de Janeiro, considering that it is not the responsibility of the Municipality to offer Higher education, this change in the scenario may raise a vulnerability to the sustainability of this Institution? What do the different social actors think, who are inserted in this context of this teaching intuition? This college was and remains relevant, being the only public and nocturnal in the state?

\section{Relevance and Applicability of Search}

This research is relevant because it deals with a special case in Brazil, since it addresses a Municipal public Higher education with night courses offered in the region.

Since the research will present the unique benefits of this specific Higher education for the region, an improvement plan is proposed to the City Hall the local City Hall the need to keep this college in operation, even with the offer of the federal. 


\section{LITERATURE REVIEW}

The process of internalization of Higher education along the lines of a country like Brazil becomes a very specific theme for that country. Thus, aiming at understanding these national specificities, the data from the literature were obtained through consultation with the specific legislation, theses and dissertations dedicated on the theme, in addition to other sources of consultation, such as Institutional data from the HEl whose profile is consistent with the purposes of this research

Thus, the procedures for identification and selection of works were based on a Bibliographic Review, through books on scientific methodology, and through the Internet. The documentary research included consultation of data and studies of official research bodies, such as Legislations, Documents, Decrees and Censuses of Higher Education, from official sources, such as MEC - Ministry of Education, Federal Senate, Planalto, INEP - National Institute of Educational Studies and Research Anísio Teixeira and The Brazilian Institute of Geography and Statistics (IBGE). Also via Google, a consultation was made at the Brazilian Digital Library of Theses and Dissertations (BDTD), of the Brazilian Institute of Information in Science and Technology (IBICT), hosted at the e-mail address http://bdtd.ibict.br.

\section{The Expansion and Interiorization of Higher Education in Brazil}

Higher education begins to reach the most distant regions of the country, facilitating access to the university to an increasing number of young Brazilians who are far from the capitals.

Although very slowly, Brazil began to work more Higher education in terms of development and expansion in the government of Fernando Henrique Cardoso, in the years 1990.

The Lula government, in the 2000s, reformed Higher education by promulgating laws and decrees that were mostly previous policies for Higher education in the FHC government. The then sworn in as minister, executive secretary of the MEC, Professor Fernando Haddad, followed up and finalized the draft university reform. Among its 4 main priorities are the reform of Higher education (Santos and Cerqueira, 2009).

In the period of 2004 and 2006 there was an increase in public resources for federal Institutions of Higher education (IFES), which resulted in the "hiring of new teachers and technical-administrative servers and expansion of campuses located within the States" (Amaral, 2008).

The implementation of the reform of Higher education in Lula's government can be highlighted through concrete actions in normative texts with 4 Laws and 4 decrees. Only two decrees stand out in this work because they are directly linked to the expansion and internalization of Higher education, namely:

- Presidential Decree No. 5,622, of December 19, 2005, making distance education official, opening for the relations of technological and economic capital also of other countries. Ordinance No. 4,059, of December 10, 2004, authorizing distance education in regular courses. According to Lima (2007), it is the "conception of education as a policy of integration of peripheral countries to economic globalization and the information society and the use of ICT, which already appears in peripheral countries reduced to THE, is presented as the passport of education for the information society".

- And Decree No. 6,096 of April 24, 2007, which implements the REUNI (Program to Support Plans for Restructuring and Expansion of Federal Universities). Universities must meet, among other goals: increase vacancies in undergraduate courses, expand evening courses, promote pedagogical innovations, combat dropout, raise the approval rate to $90 \%$, reach the proportion of 18 students per teacher, courses and Higher education programs. Universities that implement the program would also have financial benefits to pursue the goals.

It is worth talking about the implementation of the "Expand" program of the Lula government, which through the foundation of the Open University of Brazil in 2006, the IFES, creating ten new universities and 48 campuses and expansion of the federal network of technological and professional education in 2006 and REUNI (Brasil, 2007). 
Yet another relevant aspect was the Education Development Plan (PDE) published in 2007, which appeared in parallel to the National Education Plan (2001-2010), which reinforces the goal of expanding night courses, as highlighted in REUNI.

President Dilma, from 2011, continued the expansion and internalization program of the Lula government reporting the construction of 4 new federal universities, the creation of 47 new university campuses and 208 new IFs. This government aimed at this theme: to expand and internalize federal institutes and universities, especially in populous Municipalities with low per capita revenue; promote the training of professionals for regional development, as well as stimulate the permanence of these professionals within the country; to enhance the function and engagement of institutes and universities as an expression of government policies in overcoming poverty and reducing social inequities and internalizing the public offering of Vocational Education and Higher Education (Brasil, Ministério da Educação, 2014).

\section{Higher Education Offered by Municipalities in Brazil}

According to the 2017 Census of Higher Education, the results of which were released by the National Institute of Educational Studies and Research Anísio Teixeira in September 2018, Brazil has $2448 \mathrm{HEIs}$, of which 296 are public and 2,152 are private, representing $87.9 \%$ of the network. Of the public, $41.9 \%$ are state; $36.8 \%$, federal and $21.3 \%$, Municipal. The Municipal Institutions of Higher Education represent $2.6 \%$ of 2448 HEls in the country, or 63 Municipal Higher education Institutions, but only $0.95 \%$ of the vacancies of these HEls in the country are Municipal ones. It is also worth saying that only $5 \%$ of The Municipal HEls are distance education program.

Table 1 includes Municipal HEls in Brazil, being complemented by subsequent analyses:

- The classification for "administrative category" is "SPECIAL" for those who charge monthly, while for the others it is "Municipal Public";

- Of the Municipal $63 \%$ are free, or rather public Municipal;

- $73 \%$ of the total municipal HEl are concentrated in the States of São Paulo with $38 \%$ and in Pernambuco with 35\%;

- São Paulo has a well-established, politically strong organization with Institutions that were founded before the promulgation of the Federal Constitution of 1988. The 26 Municipal Institutions in São Paulo are home to about 60,000 students. They are gathered in the Association of Municipal Institutions of Higher Education of São Paulo (AIMES).

- $\quad$ Rio de Janeiro that there are 3 Municipal Higher education Institutions, however the Faculty of Education of the city of Itaboraí-FEITA, is extinct according to the Education Secretariat of Itaboraí (Delci employee on 05/17/19). The Institution of Itaperuna in the north of the state, is an institute with two free courses, however they are full-time physical education courses. Therefore, it can be said that in the State of RJ there is only one municipal HEl, focus of the object of study of this research, free of charge at night, with 4 courses in the technological area producing professionals for the local market and Lakes Region in general.

Table 1. Municipal HEls in Brazil

\begin{tabular}{lcccccc}
\hline \multicolumn{1}{c}{ ESTATES } & Qtty & $\mathbf{\%}$ & Free & $\mathbf{\%}$ & Paid & $\mathbf{\%}$ \\
\hline Pernambuco & 24 & $37 \%$ & 3 & $5 \%$ & 21 & $32 \%$ \\
\hline São Paulo & 25 & $38 \%$ & 21 & $32 \%$ & 4 & $6 \%$ \\
\hline Santa Catarina & 3 & $5 \%$ & 3 & $5 \%$ & 0 & $0 \%$ \\
\hline Espírito Santo & 1 & $2 \%$ & 1 & $2 \%$ & 0 & $0 \%$ \\
\hline Goiânia & 4 & $6 \%$ & 4 & $6 \%$ & 0 & $0 \%$ \\
\hline Paraná & 4 & $6 \%$ & 4 & $6 \%$ & 0 & $0 \%$ \\
\hline Rio de Janeiro & 2 & $3 \%$ & 2 & $3 \%$ & 0 & $0 \%$ \\
\hline Tocantins & 2 & $3 \%$ & 2 & $3 \%$ & 0 & $0 \%$ \\
\hline TOTAL & $\mathbf{6 5}$ & $100 \%$ & 40 & $\mathbf{6 2 \%}$ & 25 & $\mathbf{3 8 \%}$ \\
\hline
\end{tabular}

Source: Adapted from e-MEC System - National Registry of Courses and Institutions of Higher Education (Brasil, 2019) 
Municipal Institutions of Higher education are forms of government and foundations that follow the same standards as public ones, but differ from federal or state Institutions when using market practices specific to the private sector (the collection of monthly fees, for example).

Figure 2 illustrates a high rate of $71 \%$ of enrollments in HEl being nocturnal. It can be inferred that the vast majority of students also need to work to survive and or care for their families.
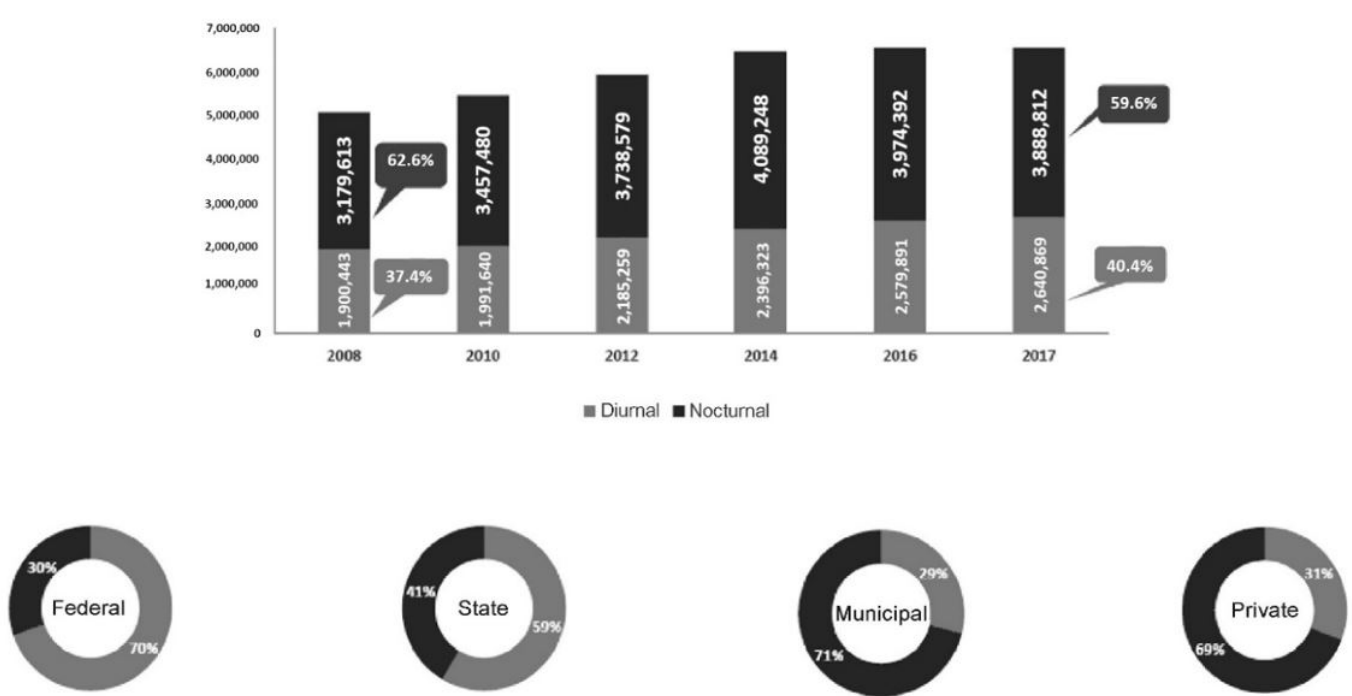

Figure 2. Number of Enrollments in Face-to-Face Undergraduate Courses, by Shift - 2008/2017 Source: INEP-Census of Higher Education (Instituto Nacional de Estudos e Pesquisas Educacionais Anísio Teixeira, 2017)

\section{METHODOLOGY}

\section{Research Ranking}

For Marconi and Lakatos (2010), research needs scientific treatments to perceive reality and truths, through formal methodologies presenting reflexive thinking method. In addition, Gil (2002) argues that this procedure results in answers to problems that hitherto are not yet clearly answered.

Thus, this research, according to the authors mentioned above, is exploratory explanatory, because it aims to provide and identify more information about the subject under investigation, which enables its better definition. In general with little known themes, as is the case of the object of this research. In general, exploratory research involves bibliographic survey, whose focus in this research is based on the literature review in the legal and normative mainstay, in Institutional documentation of Municipal Institutions of Higher education and interviews with actors who have experience with the problem researched, which makes the study quite particular in Brazilian dominance.

In addition, it is descriptive, using standard techniques for data collection, as is the case of the questionnaire. Gray (2012) figures the research as the general planning for data collection, measurement and analysis.

\section{Categorization of research subjects}

Statistically, a population involves all the elements in a given study. However, a sample is a random portion of this population. Para Sweeney et al. (2015), a sample research is a collection of data from a sample in a process of conducting a research.

In particular, the distinct groups that have influence and are influenced by the existence of the HEI under study were initially defined in this research. Moreover, in this sense, the 
research population involves all individuals who have the same characteristics defined for a given study; the sample consists of part of the population selected according to some criterion of representativeness (Silva and Menezes, 2005).

Thus, through questionnaires and interviews, the primary research is carried out with the then identified multiple stakeholders of the municipal HEl studied, directly or indirectly, internal or external, who have influence and are influenced by it, among which:

- Municipal Department of Education: In the people of the Municipal Secretary of Education, Deputy Secretary of Higher Education (Director of the URFJ of the Municipality) and Human Resources Manager. (3 interviews);

- The HEI Board, represented by the director and deputy director (responsible pedagogue).

(2 interviews);

- Coordination of Teaching Research and Extension. (2 interviews);

- Coordination of Teaching and Courses. (5 interviews);

- $\quad$ Faculty. (60 questionnaires);

- $\quad$ Student body. (1,200 questionnaires);

- Administrative Technical Staff. (8 questionnaires);

- Companies in the city. (18 interviews);

- Local community - Parents of students. (30 questionnaires).

The samples in this research are not considered as probabilistic, since they are not supported in statistical methodologies. The type of sample was selected by typicality, i.e., individuals with representativeness in the population were selected (Vergara, 2000) and the sample aims at the population, according to the list of stakeholders mentioned above.

\section{Data collection techniques}

Secondly, Marconi and Lakatos (2010), there are several existing procedures for data collection of a research. They differ according to the means or with the type of research that is intended to do.

This research was initially based on data collection through a literature review (secondary sources), based on the review of academic, official governmental and normative literature, as well as on Institutional documentation of HEl. After the aforementioned phase, considering the survey conducted in this first phase of research, two methods of data collection are elaborated: questionnaires and interviews, whose focus is precisely to answer the objectives to the previously declared research questions of this study.

In this research, we use the semi-structured interview model and mixed questionnaire, which includes the two types of questions, whose answers will be opened or closed. These questionnaires and scripts for interviews were elaborated differently according to the group to be researched.

Part of the questionnaire was conducted the Likert survey for direct comparison between the groups.

\section{Pre-testing of data collection instruments}

Pre-testing has as main objectives: to verify if there are flaws in the questionnaires and or interviews; check the levels of understanding and understanding; ensure the specificity of the questions and identify opportunities for improvement (Turrioni and Mello, 2012)

\section{Data analysis procedures}

For the analysis of the data collected in this research, the triangulation of data from different collection processes is used for subsequent confrontation between them.

To this end, sector charts and bars will present descriptive analyses.

As stated Flick (1992, p. 175), "triangulation is used to designate the combination of various methods, study groups, local environments and different theoretical perspectives to deal with a phenomenon". 
Supporting triangulation, discourse, data and descriptive statistics analysis are used in the evidence of the present study that is composed of the literature review, as detailed previously, Institutional data from the HEl and the Institution under study itself, conducting interviews and applying questionnaires with different populations involved in some way with the Institution, the object of this study.

\section{Method limitations}

It is valid to clarify the statement of both (Gray, 2012; Vergara, 2000) that any research method is subject to limitations and therefore it becomes important to anticipate possible criticism. In this research, there may be the possibility of insertion of bias by the author of the same, since he is a professor of this HEl, object of study of this research.

In addition to the above-mentioned aspects, the HEls employees questioned may omit some points because they are not politically comfortable to fully expose their opinions and or misinterpret the questions.

\section{ANALYSIS AND DISCUSSION OF RESULTS}

\section{Characterization of the Sampled Groups}

The groups of multiple stakeholders of the HEl studied were chosen because they have influence or are influenced, directly or indirectly, internally or externally, by it.

There are multiple heterogeneous groups of stakelhoders from the region impacted by a large local organization. According Campos et al. (2018), it is of paramount importance the participation and involvement of all multistakeholders ensuring the effectiveness of this organization.

Table 2 consolidates the number of each group of respondents who participated in the survey through interviews and the number that participated through the questionnaire.

Table 2. Sample Groups by Contact Method

\begin{tabular}{|c|c|c|c|c|c|c|}
\hline Groups & Stakeholders & Process & $\begin{array}{l}\text { Expected } \\
\text { Population }\end{array}$ & PERF & ORMED & \\
\hline 1 & City Hall managers & Interview 1 & 5 & 2 & $40 \%$ & $40 \%$ \\
\hline \multirow{3}{*}{2} & HEI Direction Managers & Interview 1 & 2 & 2 & $100 \%$ & \multirow{3}{*}{$88 \%$} \\
\hline & HEI Coordination Managers & Interview 1 & 7 & 5 & $71 \%$ & \\
\hline & HEI Admin Technician Mgrs & Interview 1 & 8 & 8 & $100 \%$ & \\
\hline \multirow{2}{*}{3} & HEI Teachers & Interview (Question. 1) & 22 & 22 & $100 \%$ & \multirow{2}{*}{$70 \%$} \\
\hline & HEI Teachers & Question.1 & 38 & 20 & $53 \%$ & \\
\hline 4 & HEI Students & Question.2 & 1200 & 265 & $22 \%$ & $22 \%$ \\
\hline 5 & Parents / Responsibles & Question.3 & 30 & 16 & $53 \%$ & $53 \%$ \\
\hline \multirow{2}{*}{6} & Companies in the region & Interview 2 & 3 & 3 & $100 \%$ & \multirow{2}{*}{$100 \%$} \\
\hline & Companies in the region & Question. (Interview 2) & 15 & 15 & $100 \%$ & \\
\hline
\end{tabular}

Source: The authors themselves

\section{City Managers Group}

In this group, the deputy undersecretary of Higher education has a position of relevance, since it is directly related to the management of the university city, which comprises the 02 federal and the Municipal, object of this study. He has been in this position for 6 years in 30 years in this area. Thus, their answers are considered of great weight in the analysis of the results presented later in this study. It can also be included in this analysis the head of the city for the HR department, with its due importance, since it is specifically in charge of this Municipal College, even more having 14 years of experience in this position and training in 
administration and post-graduate degree in HR management. It should be noted that both the undersecretary and the HR professional have no other source of income besides this position.

\section{Municipal HEI Managers Group}

Group composed of two directors, five coordinators and eight administrative technicians interviewed. This group with good professional experience according to Figures 3 to 6 . Almost $47 \%$ are in this current position over 7 years of age, as evidenced in Figure 4.

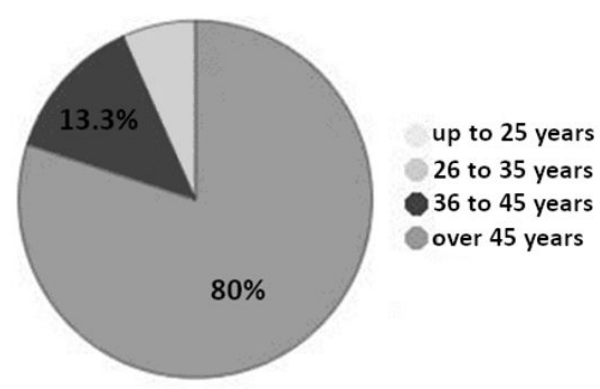

Figure 3. Age (years)

Source: The authors themselves

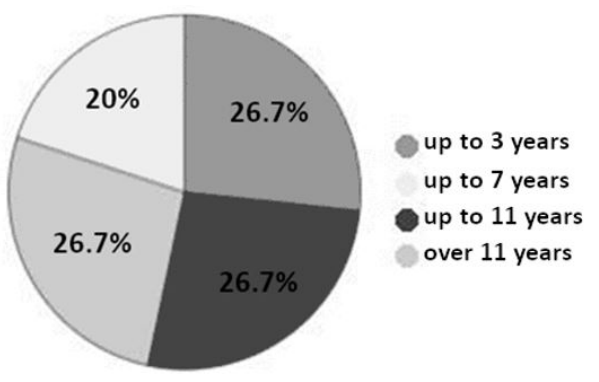

Figure 4. Working at this positio

Source: The authors themselves

All are women, $93 \%$ of whom are graduates and $80 \%$ graduate, according to Figure 5 . A fact of relevance shown in Figure 6, that their functions in HEl are directly related to their academic backgrounds.

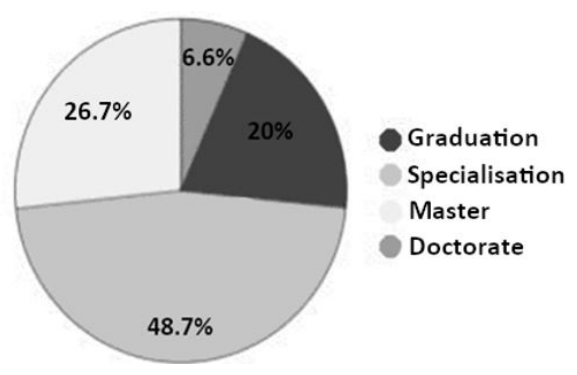

Figure 5. Academic degree level

Source: The authors themselves 


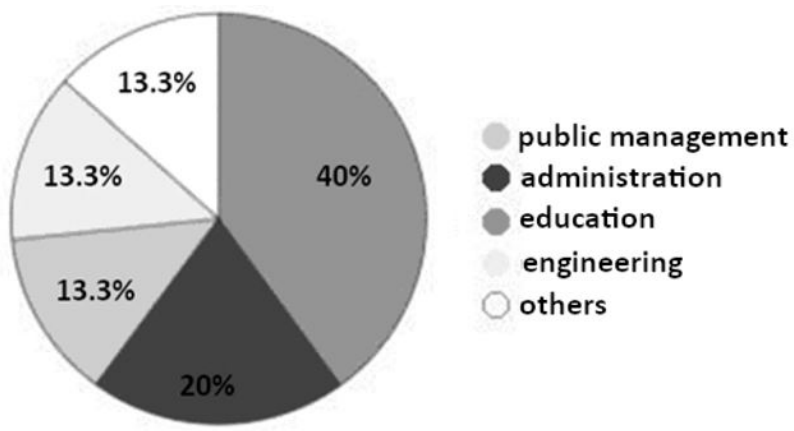

Figure 6. Graduating area

Source: The authors themselves

According to Figure 7, it is perceived that $53 \%$ of these employees have another source of income, thus not so dependent on this position, also having greater freedom and sincerity in their positions at the interview, which was well perceived.

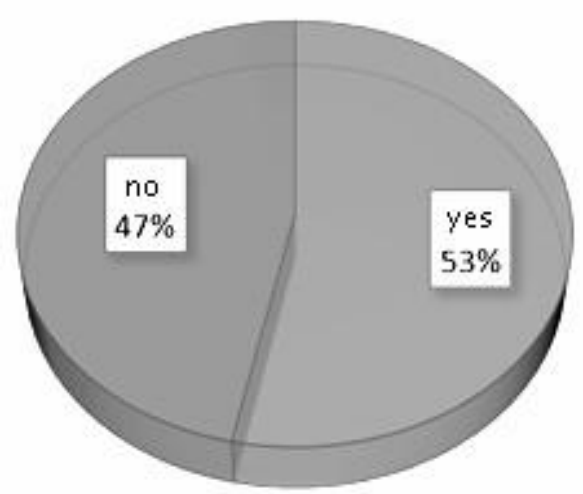

Figure 7. There is another source of income Source: The authors themselves

\section{Teachers Group}

A group of teachers, with 42 respondents, has in its education the majority of teachers as shown in figure 8 , and $45 \%$ have more than 3 years in this Institution - Figure 9.

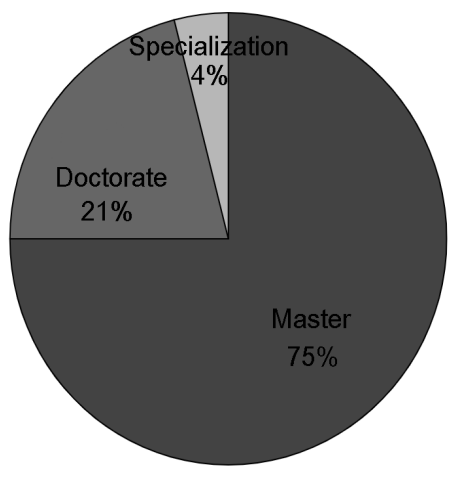

Figure 8. Academic Graduate

Source: The author themselves 


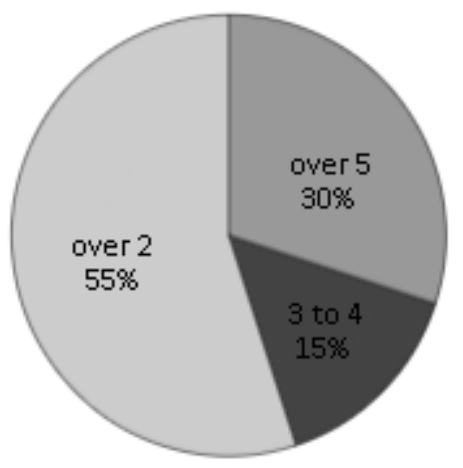

Figure 9. Teaching at this HEl (years) Source: The authors themselves

The respondent teachers are distributed in the courses according to Figure 10.

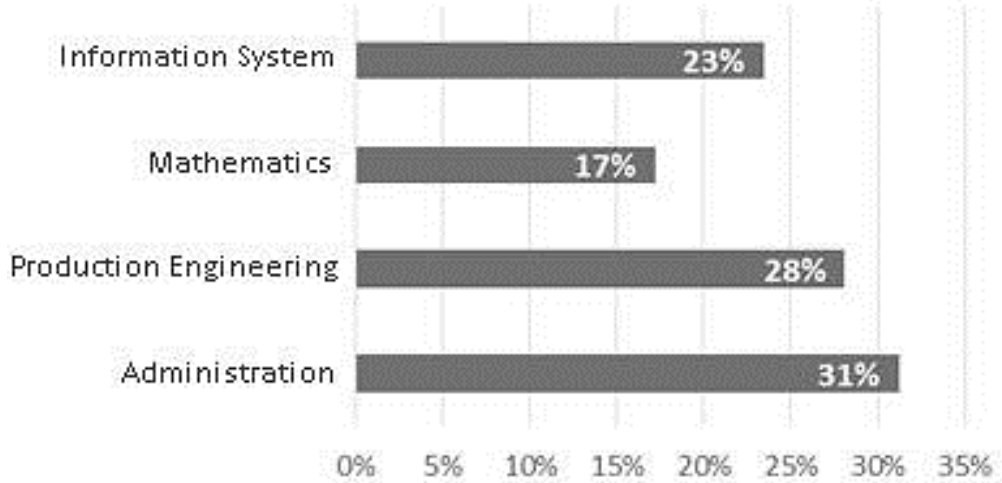

Figure 10. Teachers per course

Source: The authors themselves

And according to Figure 11, it is perceived that the vast majority of teachers, $95 \%$, have another source of income, not depending exclusively on the remuneration of this Institution.

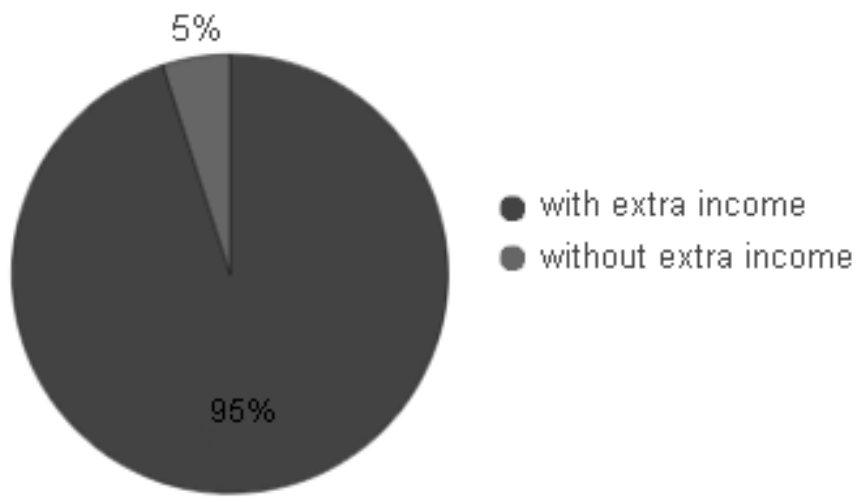

Figure 11. Teachers with extra income Source: The authors themselves

\section{Student Groups}

This is the group whose sample is 267 respondent students, $46 \%$ of them women.

The group is distributed in the four courses with predominance in the courses of production engineering and administration, as shown in Figure 12. 


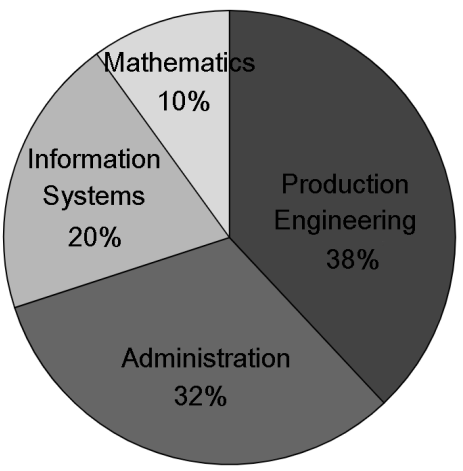

Figure 12. Students per course Source: The authors themselves

In addition, it is noted that almost $48 \%$ of the students are between 21 and 26 years old, presented in detail in Figure 13. On the other hand, it is important to consider that almost 1/4 of the respondents are over 31 years old, which suggests that the HEl studied allows older students to have access to Higher education.

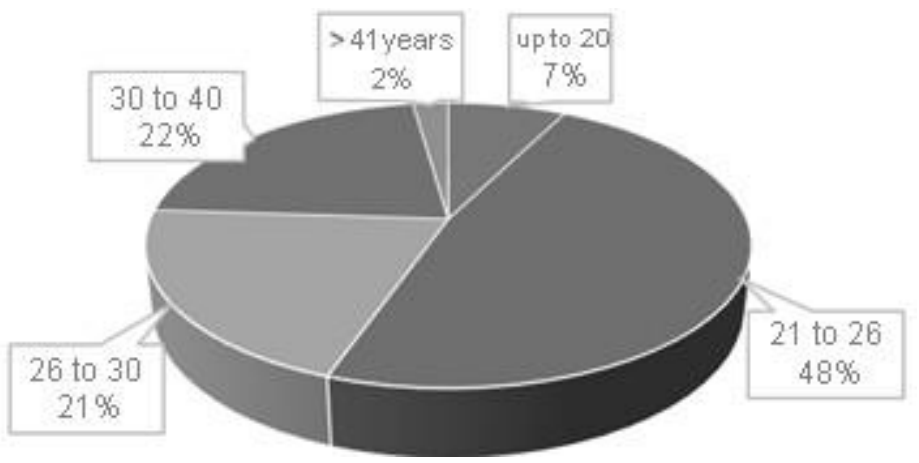

Figure 13. Age of the students (years)

Source: The authors themselves

It is interesting that $42 \%$ of the students are from the city where the HEl is studied, but today $91.7 \%$ reside in this Municipality.

This group has specific characteristics. As previously, presented most come from other cities to study and work. Corroborating this position, the research showed that $95 \%$ of the students have worked professionally and currently $77,1 \%$ study and also work or do internships as detailed in Figure 14.

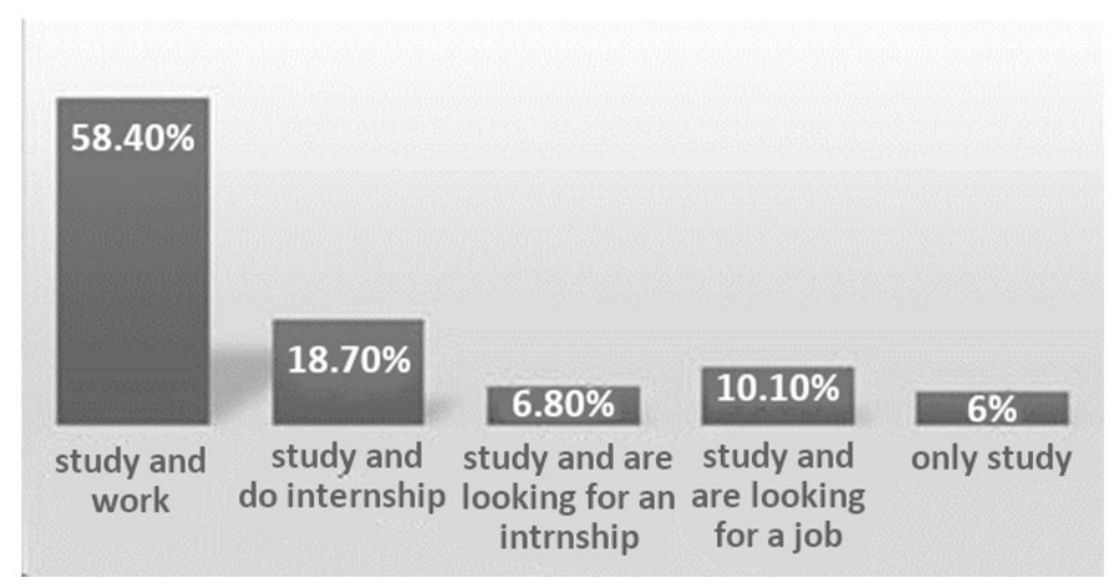

Figure 14. Occupation of the students 
It is worth noting that when they entered the university as shown in Figure 15, 70\% of the students lived with their parents and currently $57 \%$ still live with them and $31 \%$ with their partners.
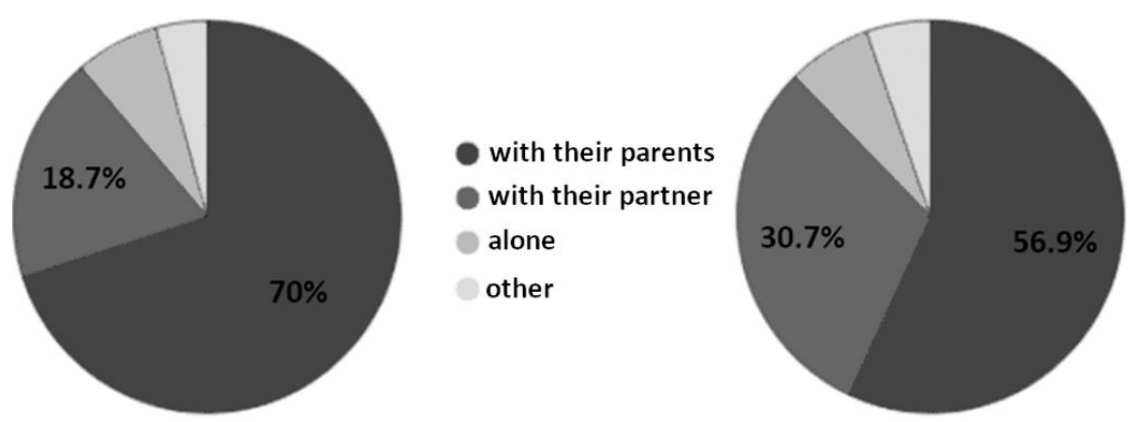

Figure 15. Housing of the students Fonte: The authors themselves

The profile of the students sampled is completed when the following figures are analyzed, because taking into account that the salaries of $75 \%$ of the students are up to $R \$ 2,500.00$ according to Figure 16 and even more than half are in the middle of the course according to Figure 17.

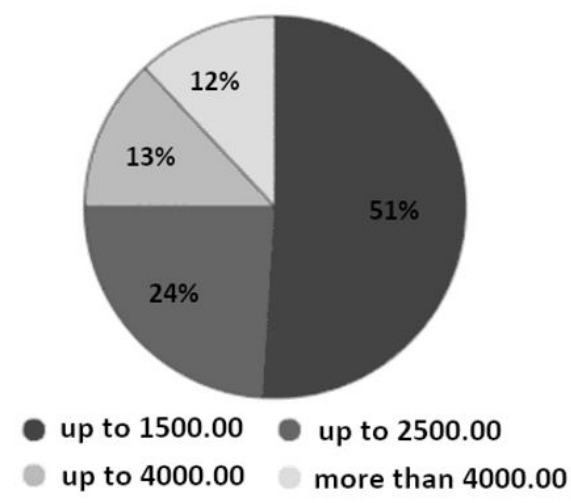

Figure 16. Income of the students Source: The authors themselves

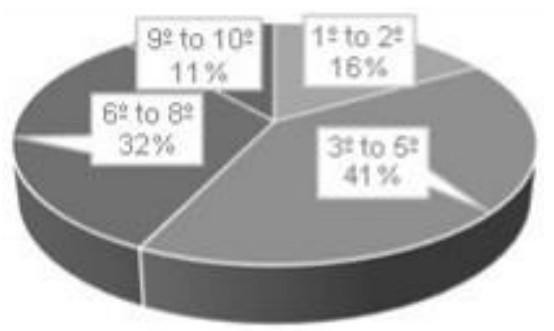

Figure 17. Period under study Source: The authors themselves

The above assumption can be reinforced taking into account that, as previously presented in Figure 14 - Student occupation, 58.4\% of students are working professionally in addition to studying and also, when observing an index of $68.9 \%$ of students who are the family breadwinner, according to Figure 18. 


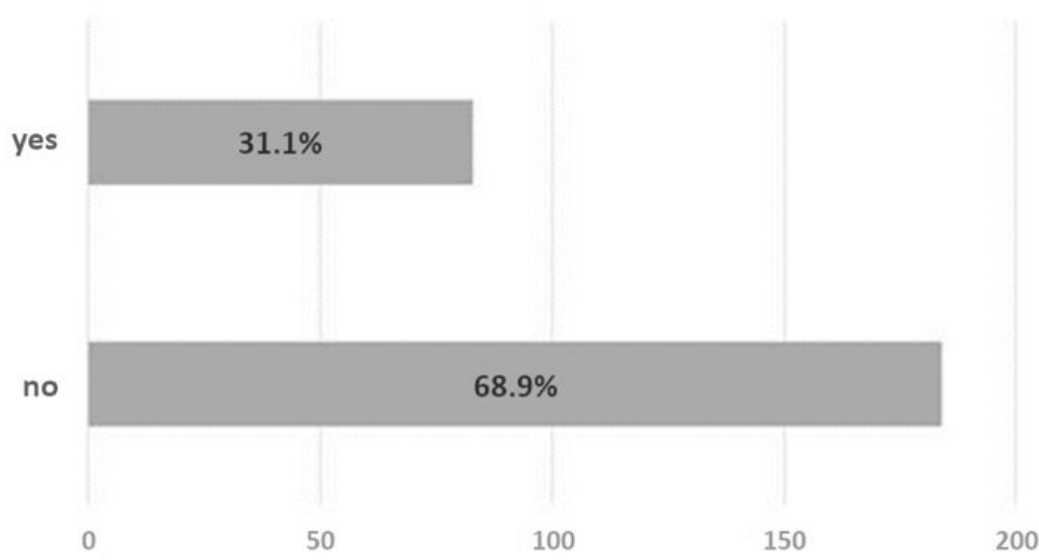

Figure 18. Students who are the family breadwinner

Source: The authors themselves

\section{Local Community Group}

The parents of the students were surveyed as representatives of the local community being indirectly influenced by The $\mathrm{HEl}$, as well as having indirect influence. All respondents live in the city of HEl studied, however $18.8 \%$ were born in it, and the rest are from cities in the state of Rio de Janeiro and almost 20\% from SP and MG.

According to Figure 19 , there is $62 \%$ of the local community from middle to low income, suggesting a difficulty in investing in a private college already for a child.

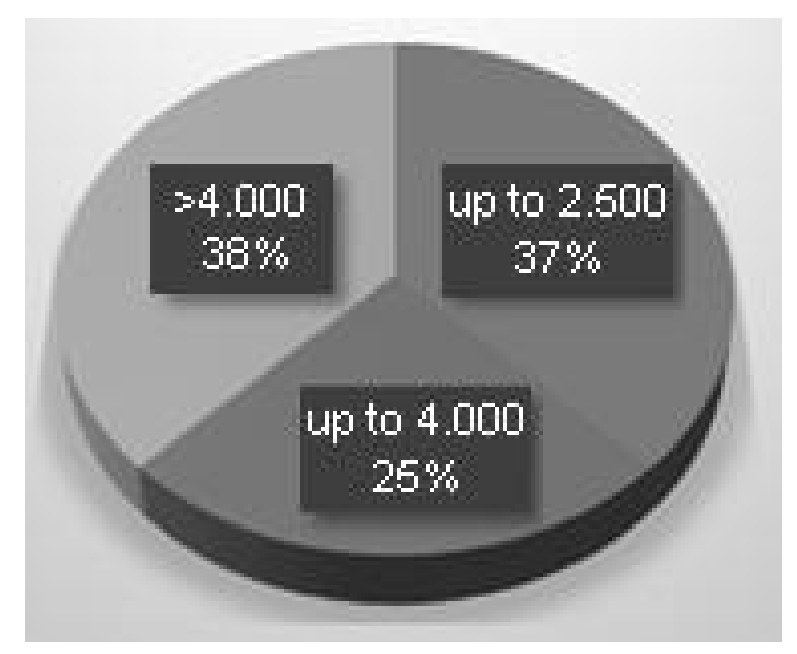

Figure 19. Familiar income

Source: The authors themselves

\section{Group Companies of the region}

The companies surveyed are in their entirety commercial and service providers in general in the area of oil and gas in the region of the north coast of Rio de Janeiro.

They are mostly large, since $61 \%$ have more than 500 employees, according to Figure 20, or cumulatively consider that $78 \%$ have more than 100 employees. However, this sample also has small and medium-sized companies, suggesting a comprehensive research result, as it contains different policies for hiring and recruiting staff, young apprentices, trainees and trainees. 


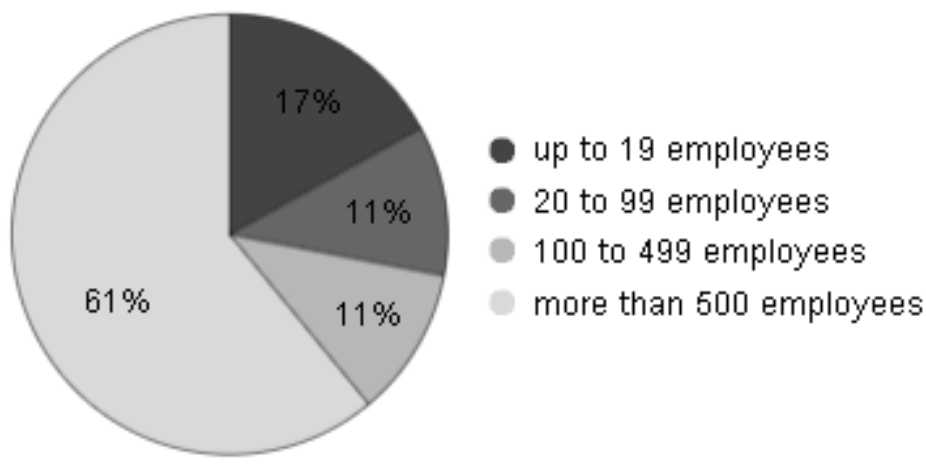

Figure 20. Company size

Source: The authors themselves

Corroborating the above position on the scope of the results of this research, Table 3 lists the diversified areas/sectors of activity of the respondents, which collaborate with different views of organizations, such as management, commercial, financial, operational techniques in general, HR and supplies.

Table 3. Area/Sector by respondent

\begin{tabular}{cc}
\hline & Respondents \\
\hline Qty & Area/sector \\
\hline 1 & Science and Technology \\
\hline 3 & Shopping \\
1 & Engineering \\
\hline 1 & Financial \\
\hline 2 & Commercial \\
\hline 1 & Construction and Assembly \\
\hline 1 & Job Planning \& Closure \\
\hline 4 & Supply Chain \\
\hline 1 & Operating \\
\hline 1 & Safety and environment \\
\hline 1 & Human Resources \\
\hline 1 & Quality/lnspection \\
\hline
\end{tabular}

Source: The authors themselves

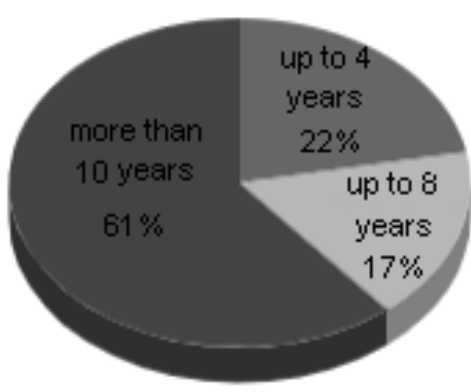

Figure 21. Respondents' professional experience Source: The authors themselves 
It is also perceived that the perceptions given by these respondents show their relevance well grounded due to their professional experiences. As figure 21 clears this statement with $61 \%$ having more than 10 years of professional experience.

All have academic experience in their areas of activity.

\section{Matrix of Influence and Power}

Once those involved by the degree of power and influence are classified, as shown in Figure 22, one can better understand the degree of impact of decisions by the city/Municipal education department, since it is the only one of the stakeholders with high power and average influence. Thus, it can be assumed that the last word about any definitions about this $\mathrm{HEI}$ is from the Municipality. On the other hand, the local community has the influence of voting in elections as a representation of local society, so the decisions of the Municipality will possibly be considered in relation to the position of the local community.

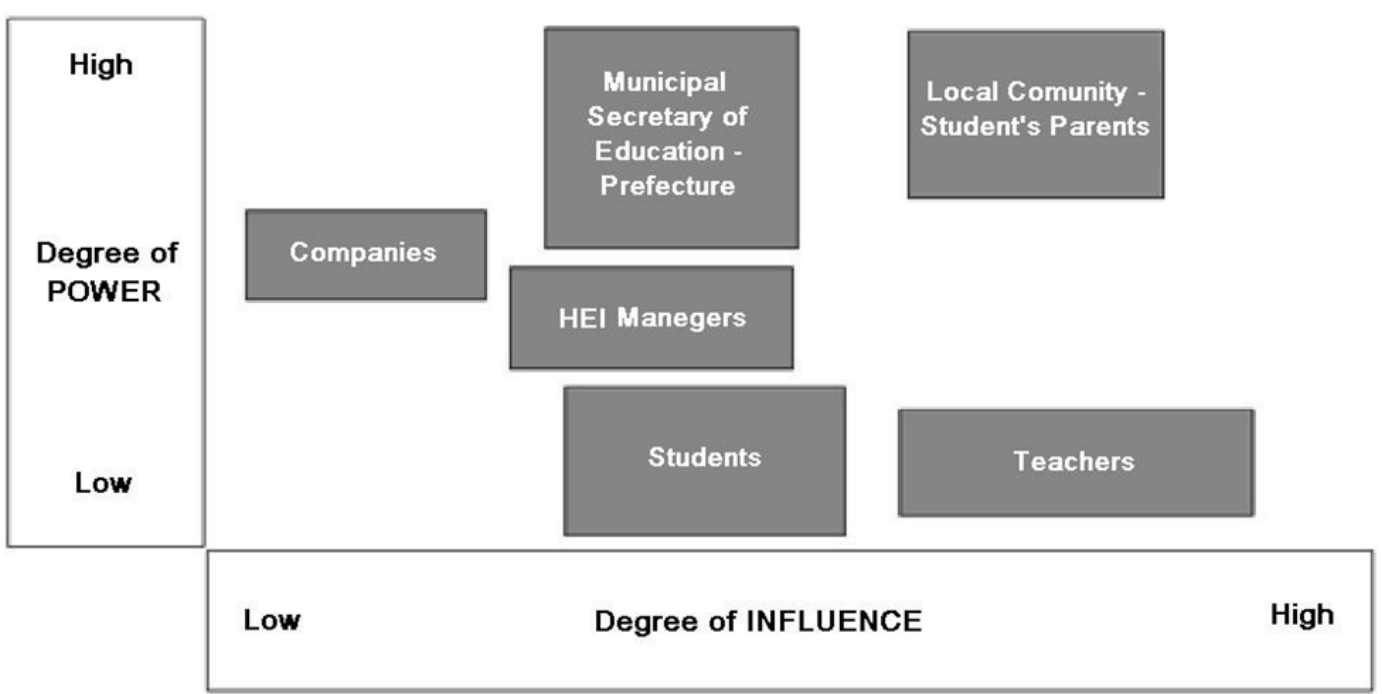

Figure 22. Power/Influence Matrix

Source: The authors themselves

\section{Confrontation between the Perceptions of Distinguished Stakeholders in Relation to the Key Attributes of the HEI Researched}

The perception of the respondents had been parameterized through a likert standard psychometric, assuming the following relevance criteria: 1: Very little; 2: Little; 3: Average; 4: High; 5: Very High.

It should be noted that due to the number (and representativeness) of the respondents per group being different, the underlying analyses were performed in percentage terms, so that possible inferences related to the criteria can be affected.

\section{Municipal HEI and Totally Free}

Undoubtedly, there is a very concrete positive position on the part of all stakeholder groups, as Figure 23, as the faculty is completely free, especially if you consider score 4 , it reaches practically $100 \%$. 


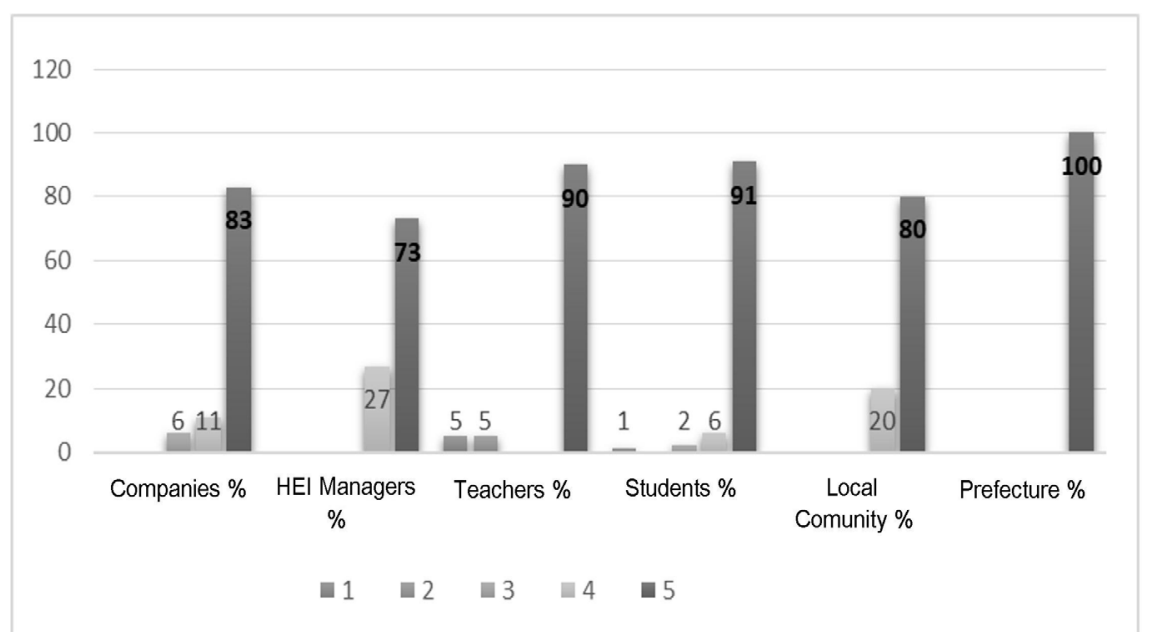

Figure 23. Municipal HEI and totally free

Source: The authors themselves

\section{Night-time HEl (After regular working hours)}

A very relevant factor is the Institution being at night. This is because there are two other federal universities in the city that are free, however in full periods, as well as other colleges at night, but are private not free! Thus, according to Figure 24, scores 4 and 5 also almost reached $100 \%$ in all groups. There is an overview of the interviewees points out that exactly these two factors together, being free and nocturnal, is what makes this HEl with an unparalleled differential in the region, because a large part of the population of the region needs to work during the day, being able to study at night, and a free college.

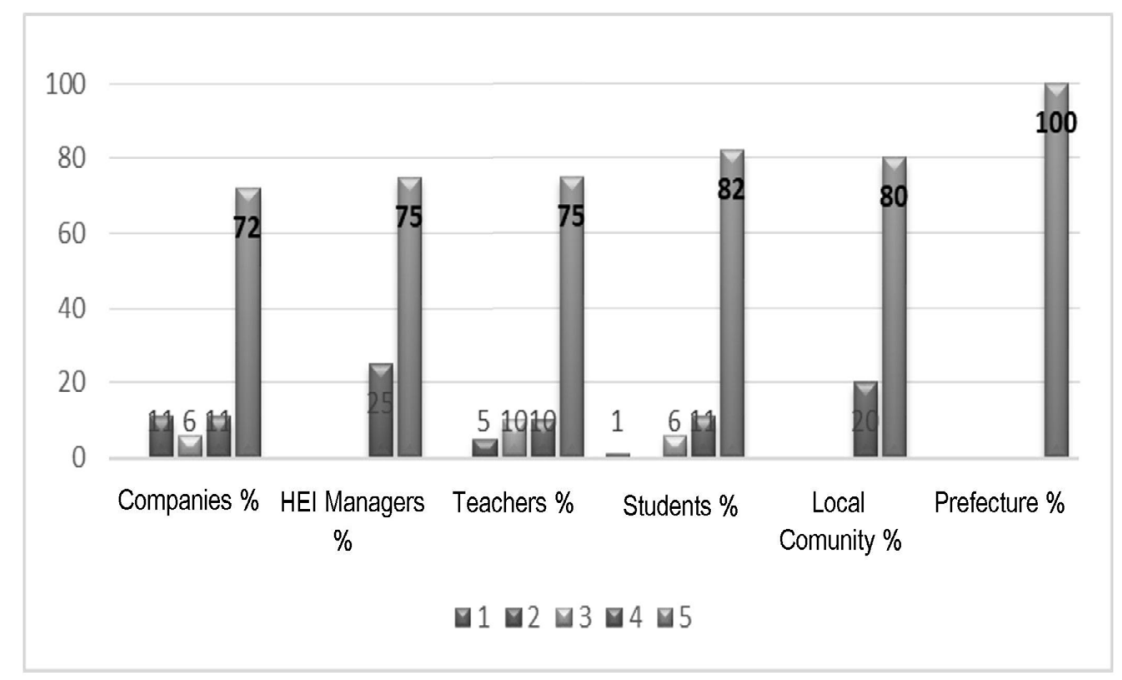

Figure 24. Night-time HEl

Source: The authors themselves

\section{Courses Oriented to Professional Practice According to the Coorporative Market in the Region}

This college has four courses. With the exception of the recently created bachelor's degree course, created by 3 others, production engineering, administration and information systems, which are well focused on the regional market, as shown in Figure 25, which was the initial purpose of the city in the creation of this HEI. And with this, stimulate the needy labor in the region to study and achieve better positions in companies in the region. On the other hand, it would also reduce the need for professionals from other states. 


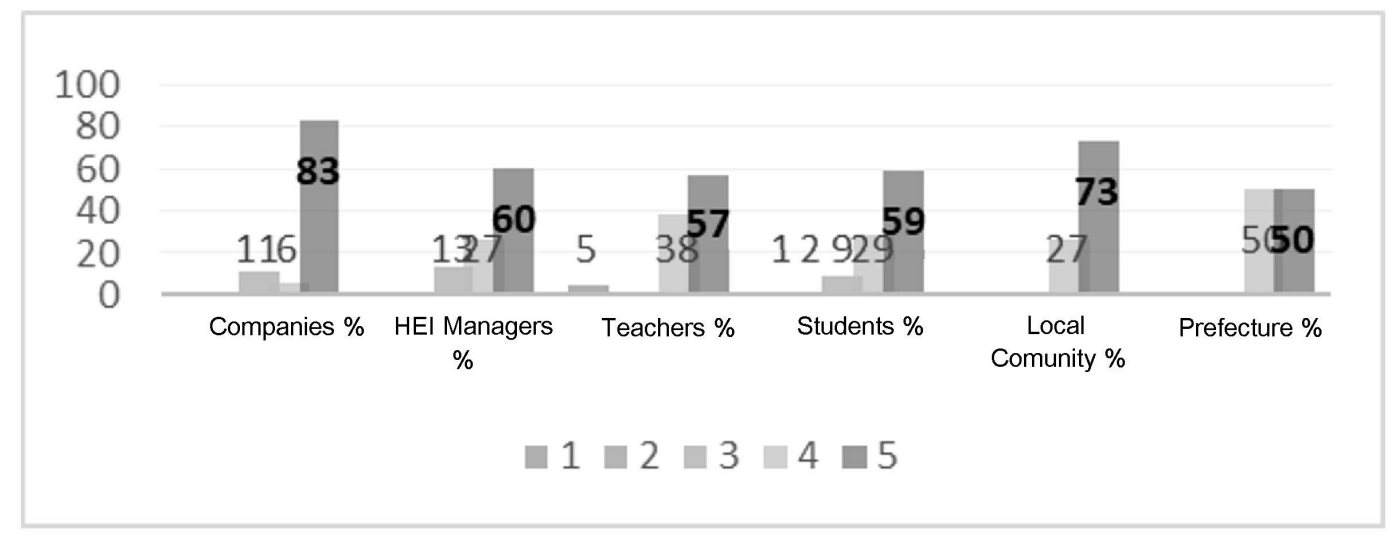

Figure 25. Courses Oriented to Professional Practice According to the Coorporative Market in the Region

Source: The authors themselves

\section{Organizational Climate. Relationship in the Faculty between Managers, coordinators, teachers, students and employees}

As expected, this factor had a good score as shown in Figure 26. Between scores 5 and 4, an average greater than $80 \%$ is perceived, confirming this positive reality of the Institution by the respondents. While the group of students shows a small drop in this average compared to the other groups.

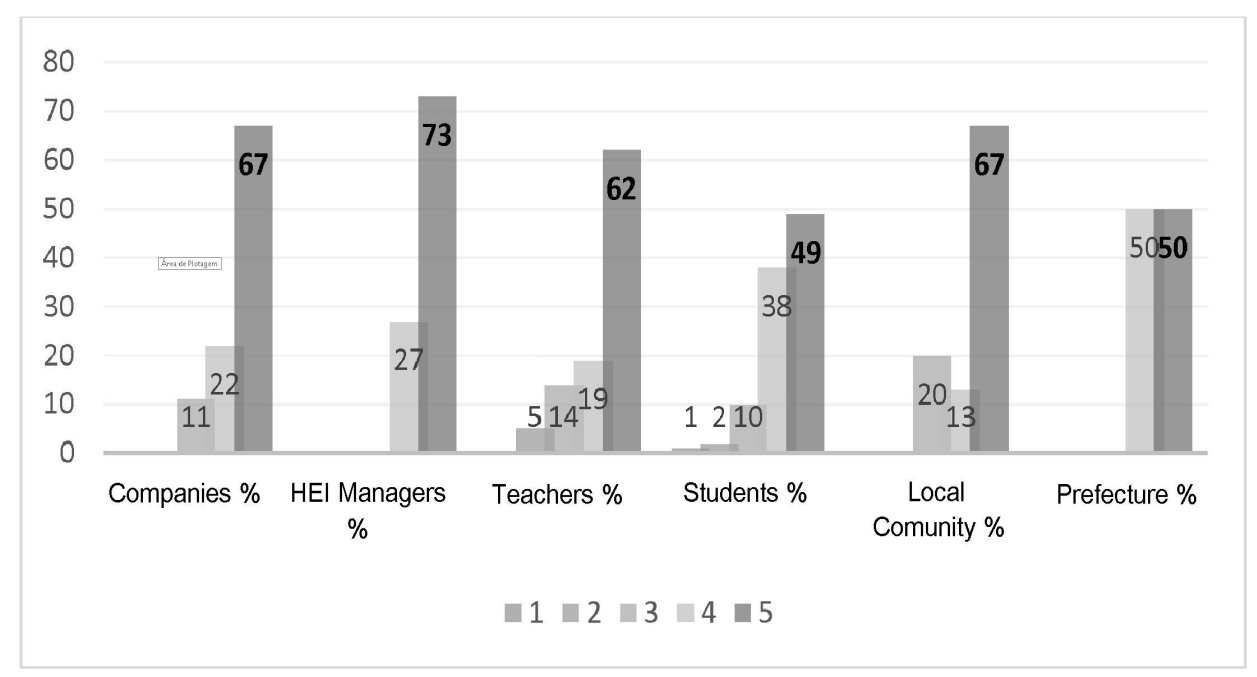

Figure 26. Organizational Climate

Source: The authors themselves

\section{Regional Labor Market Demand for College Graduates}

As shown in Figure 27, the city group understands this factor of high relevance, and its main objective is. However, the other groups understand that this phase of economic crisis taking place from 2014 to the present moment, has not offered number of effective or internship vacancies, in a satisfactory minimum number. It is true that once the market has warmed up, there is the demand of the labor market for graduates of this particular college, but the market must be heated. It is important to say that some executives interviewed say they give a certain preference for the graduates of this faculty given lived history, even compared to recent graduates from other local colleges. They believe that the graduates of this Institution are more mature and need a better source of income. 


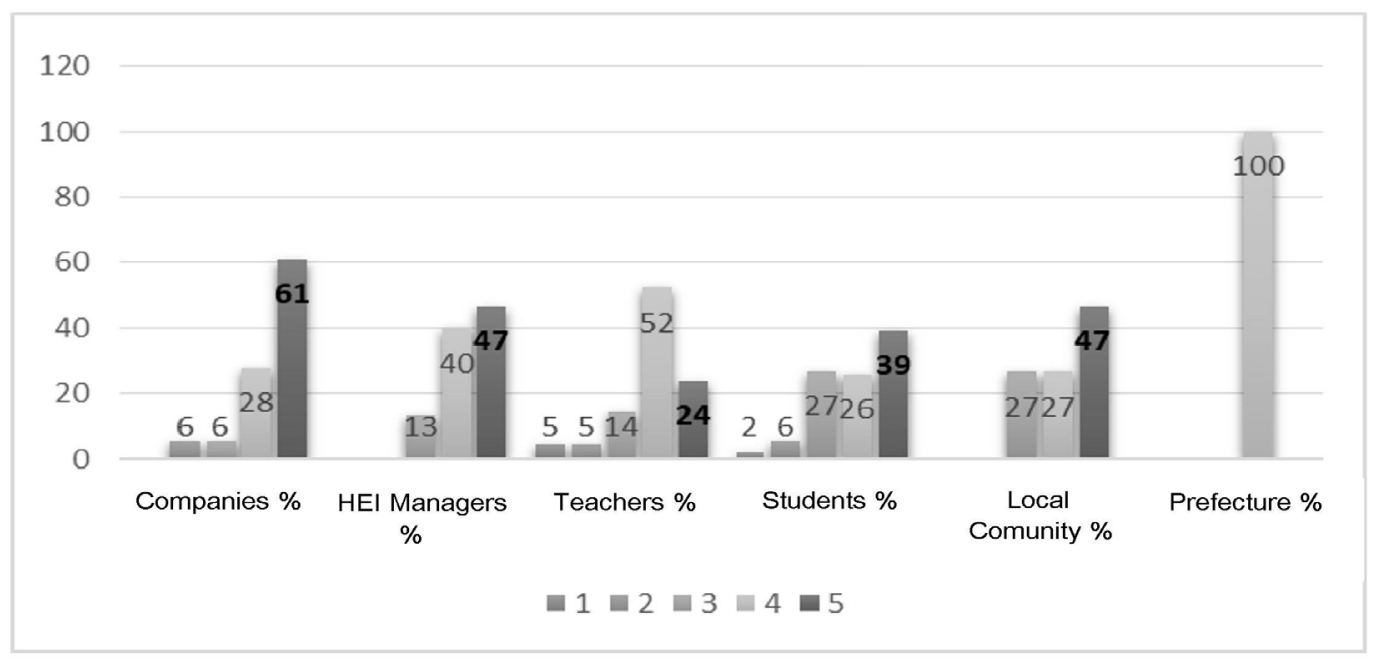

Figure 27. Regional Labor Market Demand for College Graduates

Source: The authors themselves

\section{Society need for quality and free teaching}

It is notorious the high importance given by society to a quality and free Higher education Institution according to Figure 28 Indistinctly among the groups the high score reveals the need of all stakeholders.

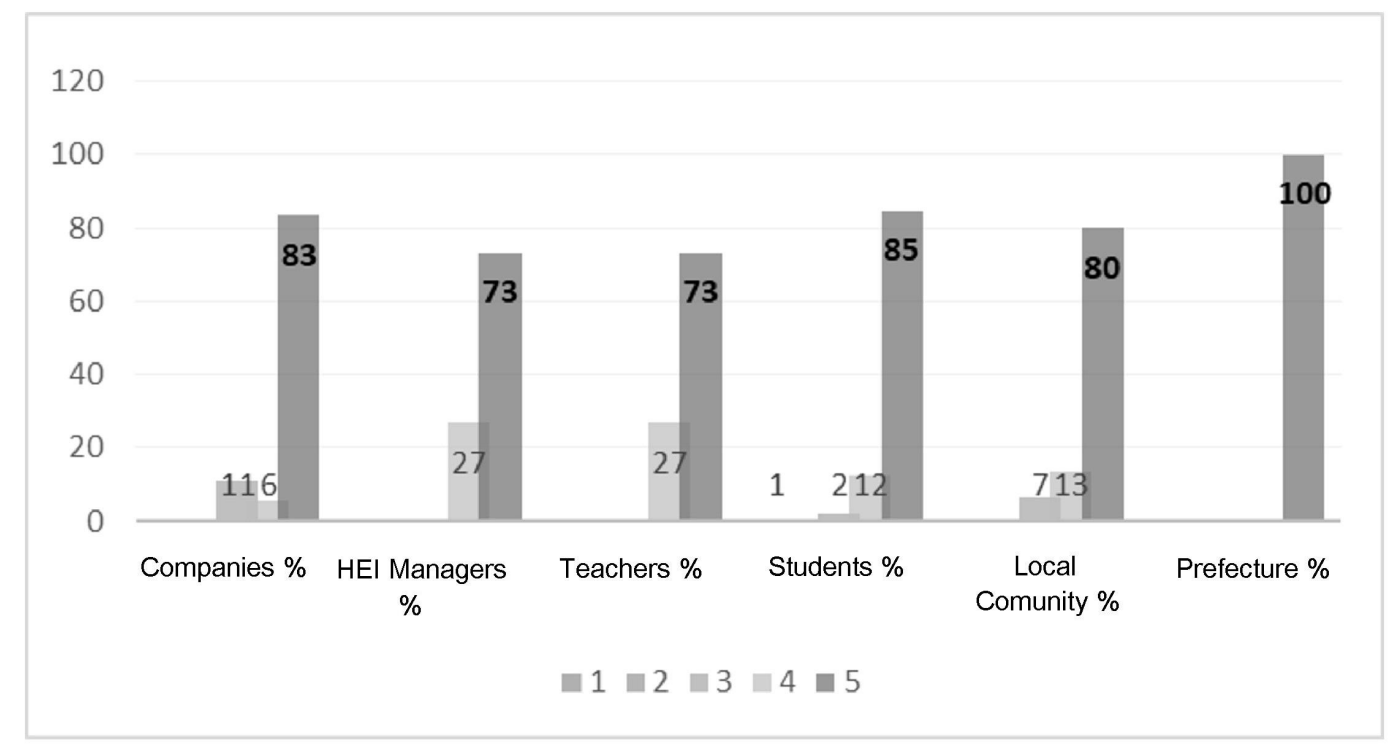

Figure 28. Society need for quality and free teaching

Source: The authors themselves

\section{Differential of This City Hall When Compared to the Others of the State}

In this respect, not everyone agrees with this position, except for the city and group of Managers of HEI, as shown in Figure 29, because they are direct employees of the Municipality.

The other groups pointed out less relevance, understanding that this creation happened 20 years ago and due to the influence of politically important families. 


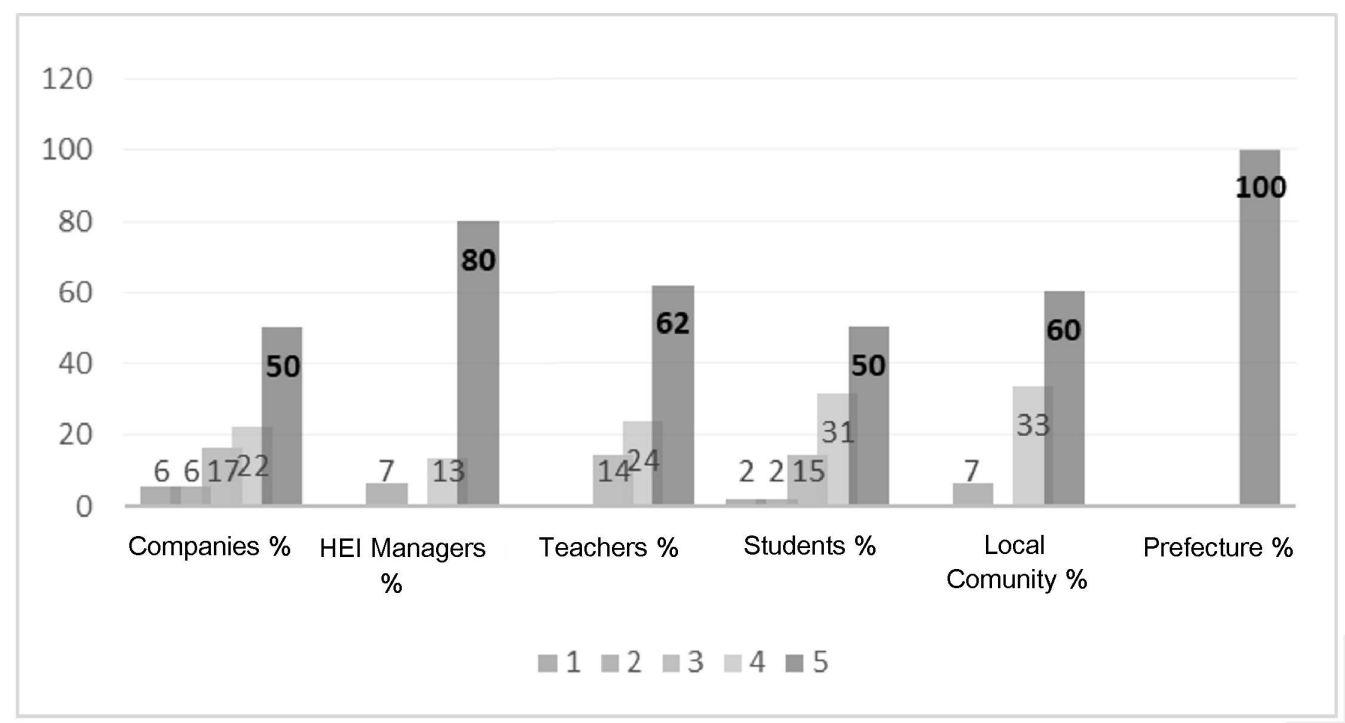

Figure 29. Differential of This City Hall When Compared to the Others of the State Source: The authors themselves

\section{Possibility of Technological Support to Companies in the Region}

This research also presents the same type of situation as the previous question. This is because the city group has $100 \%$ understood that this question points to the "possibility", according to the first word of this research, seeing the great potential for this. On the other hand, respondents from the other groups were divided between the previous position, the fact that today there is no such "support for companies" and because the faculty does not have the structure for this process of technological support to companies in the region. This analysis is according to questionnaires and interviews, presented in Figure 30.

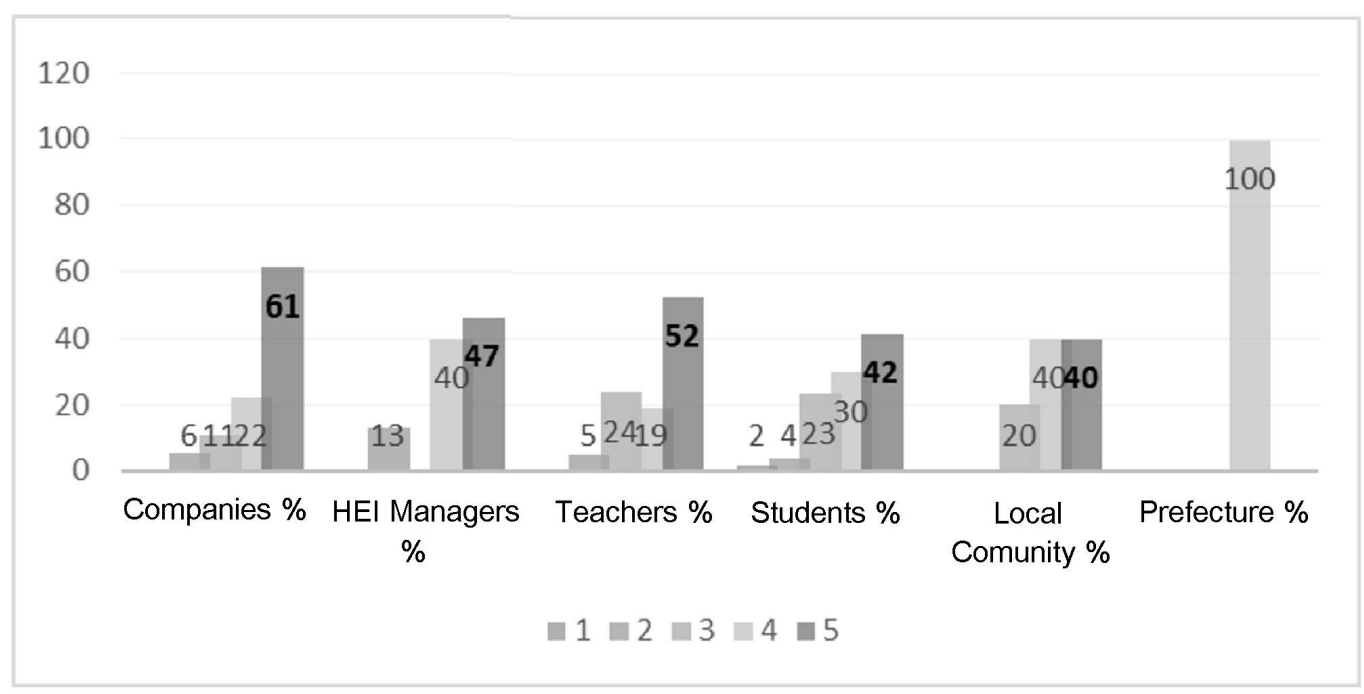

Figure 30. Possibility of Technological Support to Companies in the Region Source: The authors themselves

\section{Economic Crisis vs. Continuity of this Municipal HEI}

An issue that involves different aspects according to the interest group, was about the crisis in the oil industry and the country, and consequently impacts on the collection of the Municipality. Since this faculty is Municipal, and the city does not have direct responsibility in the provision of Higher education, it is discussed whether this change in the scenario can pose risks to the discontinuity of this Institution by the Municipality. 
As the above statement is a fact, the position of groups of students, teachers, parents, companies and even administrative technicians, is that there is rather this risk for the discontinuity of this HEl, especially in a future exchange of the city. They recall that in 2017 the Foundation was extinguished to which this Institution was part, thus referring from now on to the sub-secretary of Higher education of the city, responsible for the two federal and now also for this Municipal. It is worth remembering that at that time there was a possibility of one of the federal authorities taking over the Municipal college, however as they had no money to do so and the process was closed.

Thus, this history confirms the vulnerability of the continuity of this Institution as the groups think. Still as exposed by the respondents, the basic education network of the city is very precarious and the councilors have charged the city asking the money directed to the college.

On the other hand, it was also declared that this amount destined to Higher education in the city is very small within the current budget of the city. These values are not said by the respondents.

Even with all the situation discussed so far, there is the group of managers of HEl and the group of the city that do not believe that there is this risk for the continuity of the college. They claim that this municipality, like any other, weighs heavily on the voting strength of the community. Making it clear that this college has existed for 20 years and the city would not risk a budget, which they say is insignificant.

\section{Improvement Issues According to the Perception of Stakeholder Groups:}

Through the questionnaires and interviews, several inspired practices were raised to implement themselves in the Institution from the contribution of the different segments in semi-structured interviews with open answers, as presented in table 4.

Table 4. Stakeholders' proposals for improvements

\begin{tabular}{cl}
\hline Stakeholders & \multicolumn{1}{c}{ Suggestions } \\
\hline \multirow{2}{*}{ Companies } & - Provide intensive training in innovation technology; \\
& - Company opens its doors as a laboratory for college in exchange for R\&D \\
& work. \\
& - Promote free social projects directly to the local community; \\
& - Implement new courses in addition to the 4 existing ones; \\
Managers & - Promote Municipal HEl in the region through advertisements on TV, radio \\
& and local newspapers. \\
& - Provide services to companies in the region; \\
& - Create a Foundation in college to provide consulting services to \\
& companies; \\
& - Implementing public competitions for teachers; \\
& - Consolidate inter-institutional integration and the indissociability \\
& between teaching - research - extension. \\
\hline Students & - To promote partnerships with companies in the region; \\
& - Insert visits to companies with practical classes. \\
\hline \multirow{2}{*}{ Responsibles } & - Train incubator companies (technological hub) integrated with the \\
& department of trade and business. \\
\hline
\end{tabular}

Source: The authors themselves

\section{FINAL CONSIDERATIONS AND LIMITATIONS}

The present study aimed to investigate whether this Municipal Institution of Higher education was and continues to be relevant to the region, being the only nocturnal public in the State. Especially after the economic impact in the country initially caused by the oil crisis, thus reducing the collection of the Municipality, which in turn has no responsibility for Higher education. Thus, the objective was also to check what the different social actors think, which 
are inserted in this context of this teaching intuition and to verify whether this change in the economic scenario can cause a fragility in the continuity of this Institution.

According to Marques et al. (2018), all definitions of a large goals of an organization must be supported by stakeholders, who depend on their long-term successes, and these relationships must be worked on by their managers.

Thus, some specific objectives whose results are discriminated against below were dismembered from this one:

- The multiple stakeholders of HEl were identified and characterized;

- It was verified in relation to these actors, their levels of interest, power and development in the Institution, noting the position of the city hall/Municipal department of education, the only one of the stakeholders with high power and average influence, thus assuming that the last word about any definitions about this HEl is from the Municipality. On the other hand, the local community has the influence of voting in elections as a representation of local society, so the decisions of the Municipality will possibly be considered in relation to the position of the local community.

The mayor represented by the Municipal secretary of education has the power and clear interest, however isolated, in extinguishing this college. On the other hand, the direction, teachers, coordinators and administrative from this HEl has opposite interest, with very little decision-making power, although many have another source of income. There is still the group of students and the community with a lot of interest in the continuity of the Institution and a lot of power in the decision, by the force of the vote, as mentioned by the undersecretary of Higher education: "it would be very difficult for any mayor to want to face the population, who have this right acquired for 19 years".

Based on Endler et al. (2017), also proposes a research that deals with the evaluation of the spatial distribution of the northern region of Rio de Janeiro, relating companies according to their economic activities versus free and nocturnal HEls, with the objective of a discussion to leverage the region's economy in partnership with local communities.

Finally, it is still suggested the application of the SERVQUAL model, according to Soares et al. (2017), obtained in administrative services in a public Institution of Higher education from the perspective of the student body, aiming to evaluate the quality of the services offered to its students.

It is worth noting that this research only studied the reality of a particular Institution in the coastal region of northern Rio de Janeiro.

In this context, it is suggested that comparative studies be made with other Municipal Higher education Institutions in order to verify their points of approximation and distancing.

\section{REFERENCES}

Amaral, N.C. (2008), "Autonomia e financiamento das IFES: desafios e ações", Avaliação, Campinas, Sorocaba, Vol. 13, No. 3, pp. 647-80.

Brasil (2007), Decreto n. 6.096, de 24 de abril, Institui o Programa de Apoio a Planos de Reestruturação e Expansão das Universidades Federais. Diário Oficial da União. available at: http://www.planalto.gov.br/ccivil_03/_ato2007-2010/2007/decreto/D6096.htm (accessed 9 March 2019).

Brasil, Senado Federal (2018), LDB: Lei de diretrizes e bases da educação nacional, 2. ed., atualizada até junho, Senado Federal, Coordenação de Edições Técnicas, Brasília, available at: http://www2.senado.leg.br/bdsf/bitstream/handle/id/544283/lei_de_diretrizes_e_bases_2ed.pdf (accessed 10 March 2019).

Brasil (2019), e-MEC: Cadastro Nacional de Cursos e Instituições de Educação Superior, available at: http://emec.mec.gov.br/ (accessed 21 April 2019)

Brasil, Minitério da Educação (2011), Expansão da educação superior e profissional e tecnológica: mais formação e oportunidades para os brasileiros, available at: http://portal.mec.gov.br/expansao/images/APRESENTACAO_EXPANSAO_EDUCACAO_SUPERIO R14. pdf (accessed 28 April 2019). 
Brasil, Ministério da Educação (2014). Plano Nacional de Educação, available at: http://pne.mec.gov.br/ (accessed 17 February 2019)

Campos, L., Araujo, F., Freitas, R. et al. (2018), "Percentual Analysis of heterogenous stakeholder on the impacto of the Rio 2016 games in the territory of Lagoa Rodrigo de Freitas", Brazilian Journal of Operations \& Production Management, Vol. 15, No. 4, pp. 576-87.

Endler, K.D., Scarpin, C.T. and Steiner, M.T.A. (2017), "Proposed system for analyzing the location of preschools: a Brazilian case study", Brazilian Journal of Operations \& Production Management, Vol. 14, No. 4, pp. 446-60.

Flick, U. (1992), "Triangulation revisited: strategy of validation or alternative", Journal for the Theory of Social Behaviour, Vol. 22, No. 2, pp. 175-97.

Gil, A.C. (2002), Como elaborar projetos de pesquisa, 4. ed, Atlas, São Paulo.

Gray, D.E. (2012), Pesquisa no mundo real, 2. ed., Penso, Porto Alegre.

Instituto Brasileiro de Geografia e Estatistica - IBGE (2015), “Síntese de Indicadores sociais", available at: http://www.ibge.gov.br/home/estatistica/populacao/condicaodevida/indicadoresminim os/sinteseindicsociais2015/default_tab_xls.shtm (accessed 20 September 2019).

Instituto Nacional de Estudos e Pesquisas Educacionais Anísio Teixeira - INEP (2017), “Censo da Educação Superior: notas estatísticas". available at: http://download.inep.gov.br/educacao_superior/censo_superior/ documentos/2018/censo_da_educacao_superior_2017-notas_estatisticas2.pdf (accessed 05 March 2019).

Lima, K. (2007), Contrarreforma na educação superior: de FHC a Lula, Xamã, São Paulo.

Marconi, M.A. and Lakatos, E.M. (2010), Fundamentos de metodologia científica, 7. ed., Atlas, São Paulo.

Marques, V.L., Alledi Filho, C., Pereira, F.N. (2018), "Tools for the strategic management of stakeholders in civil construction", Brazilian Journal of Operations \& Production Management, Vol. 15, No. 4, pp. 595-609.

Melo, T.G.S. and Moura, D.H. (2017), "PNE (2001-2010), PNE (2014-2024): orientações para a Educação Profissional no Brasil", HOLOS, Vol. 33, No. 3, pp. 3-15. http://dx.doi.org/10.15628/holos.2017.5766.

Nascimento, F.S. (2013), Expansão e interiorização das universidades brasileiras: uma análise do processo de implementação do campus Litoral Norte da Universidade Federal da Paraíba, Dissertação de Mestrado, Universidade Federal da Paraíba, João Pessoa.

Santos, A.P. and Cerqueira, E.A. (2009), "Ensino Superior: trajetória histórica e políticas recentes”, in IX Colóquio International sobre Gestão Universitária na América do Sul, Florianópolis, SC, pp. 1-17.

Silva, E.L. and Menezes, E.M. (2005), Metodologia da pesquisa e elaboração de dissertação, 4. ed., Departamento de Ciência da Informação, Universidade Federal de Santa Catarina, Florianópolis, SC.

Soares, M.C, Novaski, O. and Anholon, R. (2017), "Servqual model applied to Higher education public administrative services", Brazilian Journal of Operations \& Production Management, Vol. 14, No. 3, pp. 338-49.

Souza, D.B. (2014), "Avaliações finais sobre o PNE 2001-2010 e preliminares do PNE 2014-2024", Estudos em avaliação educacional, Vol. 25, n. 59, 2014, pp. 104-70.

Sweeney, D.J., Williams, T.A. and Anderson, D.R. (2015), Estatística aplicada à administração e economia, 3. ed., Cengage Learning, São Paulo.

Tavares, L. (2013), Vinte e um Anos de Educação Superior Expansão e Democratização, Cadernos do GEA, n. 3, FLACSO, GEA, UERJ, LPP, Rio de Janeiro.

Turrioni, J.B. and Mello, C.H.P. (2012), Metodologia de Pesquisa em Engenharia de Produção, Universidade Federal de Itajubá, Itajubá.

Vergara, S.C. (2000), Projects and Research Reports in Administration, 3. ed., Atlas, São Paulo.

Author contributions: Ridley Gomes Franzoso: data collection, writing, managing the project. Fernando Oliveira de Araujo: review, managing the project. Chrystyane Gerth Silveira Abreu: review, managing the project. 